\title{
Jeszcze w sprawie genezy terminu "fraszka”
}

Wedle powszechnie aprobowanego przekonania tym, dzięki któremu w zasobie leksykalnym szesnastowiecznej polszczyzny znalazł się, przeniesiony do niej z mowy Dantego Alighieri i Giovanniego Boccaccia, wyraz „fraszka”, jest nie kto inny, jak Jan Kochanowski. Jeżeli już jakaś kwestia wywoływała dotąd pewne różnice zdań w tym względzie, to nie sam prymat na tym polu rodzimego arcypoety, a raczej sposób rozumienia przezeń rzeczonego leksemu. Najbardziej radykalny, przypomnijmy, pogląd w tej mierze zaprezentował Sante Graciotti, który stwierdził, iż Kochanowskiemu obce było swoiste, literackie znaczenie „fraszki” (takie nadać mieli mu je dopiero jego naśladowcy), a jeśli go używa, to wyłącznie w sensie obiegowym, jako „drobiazg”, „rzecz niegodna uwagi”, przy czym do kategorii tej włącza on własne polskojęzyczne epigramaty'. Tezę tę daje się dość łatwo podważyć przypomnieniem zależności, w jakie wplata autor swoje poetyckie nugae poprzez nadanie im takiego a nie innego tytułu, względem pozostałych zbiorów wydawanych przez niego pod koniec życia. Trudno przyjąć, by w momencie publikacji swojej antologii nie traktował on pojęcia „fraszka” również w sensie stricte genologicznym, tak jak adekwatne wobec niego nazwy gatunkowe w tytułach Trenów, Pieśni trzech, Elegii ksiąg czworo, Foriceniów czy Pieśni ksiag dwojga.

Wydaje się bowiem, iż wysiłek twórczy Kochanowskiego w końcowym okresie życia ukierunkowany był nie tylko na sumowanie i porządkowanie dotychczasowego dorobku, ale i na przydawanie poszczególnym jego częściom określonych

* Dr, Uniwersytet Warszawski, Instytut Literatury Polskiej, Zakład Literatury i Kultury Epok Dawnych, ul. Krakowskie Przedmieście 26/28, oo-927 Warszawa; e-mail: rrusnak@uw.edu.pl

1 S. Graciotti, Fraszki i „fraszki”. Z Padwy do Polski, w: tenże, Od renesansu do oświecenia, t. 1, PIW, Warszawa 1991, s. 229. 
kwalifikacji gatunkowych. Poręczny neologizm, wcześniej ewokujący m.in., pozorną przynajmniej, dezynwolturę wobec własnej poezji, a zarazem uwydatniający jej zakorzenienie $\mathrm{w}$ przyjętej przez autora, uogólniającej refleksji antropologicznej („Fraszki to wszytko, cokolwiek myślemy, / Fraszki to wszytko, cokolwiek czyniemy"2), wydrukowany na karcie tytułowej zbioru, staje się formułą nadrzędną wobec najprzeróżniejszych pomieszczonych w nim typów wypowiedzi: od anakreontyków po poważne w tonie epitafia, od obscenicznych żartów po kierowane do Boga modlitwy. W dodatku formułą niebędącą prostym odpowiednikiem „epigramatu” - tak jak nie jest nim i wykoncypowany przez Mikołaja Reja "figlik" - gdyż noszącą w sobie nade wszystko istotny ładunek sensu pierwotnego, co w tym wypadku, jak się wydaje, oznacza odwoływanie się mniej do formalnej zwięzłości określanych tym sposobem tekstów, bardziej do wspomnianej szerokiej perspektywy ideowej. Stąd też pewnie eksponowana pozycja zacytowanej tu fraszki $O \dot{z} y$ wocie ludzkim (I 3), silnie spojonej z inicjalną, autotematyczną częścią księgi pierwszej.

Jeżeli w jakimś jednak stopniu można zgodzić się z ujęciem Graciottiego, to z tą jego obserwacją, iż propozycja terminologiczna Kochanowskiego o tyle liczyć mogłaby na swój właściwy status, o ile - w przeciwieństwie do na przykład „figlika" - znalazłby się choć jeden naśladowca, który zechciałby tym mianem opatrzyć swoje własne utwory, a tym samym sprawić, by termin, dotąd obsługujący wyłącznie jeden $\mathrm{z}$ istniejących elementów rzeczywistości (za takowy uznać by tu trzeba trzy księgi czarnoleskiej antologii), dotyczyć zaczął całej ich klasy. Wobec takiego postawienia sprawy szczególne znaczenie mieć będzie nie, często przy tej okazji wymieniany, Wespazjan Kochowski i jego Epigramata polskie, po naszemu Fraszki (1674), lecz współczesny autorowi Satyra Melchior Pudłowski, który swoich Fraszek ksiege pierwsza (1586) podał do druku już w dwa lata po swym „mistrzu”. Fakt ten w kontekście ówczesnego rozpowszechnienia się również genologicznego sensu omawianego leksemu wydaje się niezwykle znaczący. Ale przywołania godny jest tu jeszcze co najmniej jeden szesnastowieczny autor, mianowicie Mikołaj Sęp Szarzyński, w którego zbiorze wszak figuruje Fraszka $z$ Martialisza (oraz Z tegoż fraszka), ta o królu Agatoklesie, choć zważywszy na przypuszczalny czas śmierci poety, taki a nie inny jej tytuł mógł wyjść raczej od bezpośredniego wydawcy Rytmów, zrodzić się zatem około roku 1601.

Uwagi na marginesie rozprawy Graciottiego przywiodły nas w gruncie rzeczy do ujęcia obserwowalnej tu semantycznej specyfikacji zaadaptowanego z włoszczyzny leksemu w postaci triady: „drobiazg, błahostka, rzecz niegodna uwagi” - „drobny utwór literacki” - „pokrewna antycznemu epigramatowi nazwa gatunkowa”. A to odpowiadałoby porządkowi naturalnemu z lingwistycznego punktu wi-

2 Cyt. za: J. Kochanowski, Fraszki, oprac. J. Pelc, Zakład Narodowy im. Ossolińskich, Wrocław 1998, BN I 163, s. 5 (O żywocie ludzkim: I 3). Wszystkie cytaty ze zbioru Fraszek za tym wydaniem. 
dzenia: wyraz o znaczeniu dosłownym - wyraz o znaczeniu przenośnym - mniej lub bardziej utrwalone pojęcie. Choć dodać by trzeba, że w porównaniu z włoskim rzeczownikiem „frasca” już pierwszy z wypunktowanych członów tak naprawdę mieści $\mathrm{w}$ sobie metaforyczne odniesienie do pola semantycznego $\mathrm{z}$ zakresu botaniki ${ }^{3}$.

Poszczególne fazy wskazanego tu procesu dają się w określonej mierze ująć $\mathrm{w}$ ich następstwie czasowym, choć granice pomiędzy nimi uznać wypada za co najmniej płynne i trudne nieraz do ścisłego wyznaczenia. I tak jak w ostrożnej polemice $\mathrm{z}$ Graciottim moment bezsprzecznego genologicznego zastosowania „fraszki” wyznaczyć przyszło nam na czas ostatecznej publikacji zbioru, mimo iż doszukiwać by się można podobnego sensu i w konkretnych utworach powstałych na długo przed 1584 r., tak i poszczególne użycia tego leksemu nastawione są na jednoczesne uruchamianie znaczenia zarówno tego bardziej obiegowego, jak i stricte już literackiego, a poeta - jak dobrze o tym wiadomo - $\mathrm{z}$ dużym upodobaniem i po wielekroć ową semantyczną migotliwość wykorzystuje. Wystarczającym przykładem niech będzie tu fraszka o numerze I 1, a więc poniekąd warunkująca inne podobne gry polisemią pojawiające w dalszej części zbioru. To w jej zakończeniu świeżo upieczony nabywca książki dowiaduje się, iż jeśli „dał co z taszki”, nie kupił nic innego, ,jed no fraszki” (I 1, w. 5-6).

O zasadności przyjętego w naszych rozważaniach ujęcia diachronicznego, wedle którego z konkretnymi znaczeniami dopiero co zaszczepionego na grunt polski leksemu w sposób nierozłączny wiąże się czynnik temporalny, przekonuje prosty, acz rzadko zauważany fakt, jaki dotyczy wymownej rozbieżności w tytułach obu zbiorów epigramatycznych, wydanych przez Kochanowskiego praktycznie równocześnie. O ile bowiem w przypadku tekstów polskojęzycznych autor poprzestaje na pojedynczym mianie: Fraszki, łacińskie Foricoenia zyskują dodatkowo znamienne dopowiedzenie: sive epigrammatum libellus.

Oczywiście, rozbieżność tę potraktować można jako jeszcze jeden ważny argument za rzeczywistą jakościową różnicą pomiędzy oboma zbiorami, za jaką optują chociażby Stefania Skwarczyńska i Jörg Schulte, a której zasadniczym znamieniem ma być, ewokująca określony stosunek względem literackiej przeszłości, odmienność językowa ${ }^{4}$. W świetle takiego ujęcia rozszerzona formuła tytułu Foricoeniów wskazywałaby na bezpośrednią więź łacińskiej kolekcji z odziedziczonymi po

3 Interesujące poszerzenie ewokowanych przez termin "fraszka" semantycznych odniesień do języka włoskiego przynosi czwarty rozdział ostatniej książkowej publikacji Mirosława Lenarta - tenże, Patavium, Pava, Padwa. Tło kulturowe pobytu Jana Kochanowskiego na terytorium Republiki Weneckiej, Wydawnictwo IBL PAN, Warszawa 2013, Studia Staropolskie, Series Nova, t. XXXIII, s. 98-141. Z ostatnio opublikowanych studiów zob. również: J. Bedyniak, Semantyka nazwy "fraszka” a konteksty kulturowe, "Pamiętnik Literacki” 2018, z. 1, s. 6.

4 S. Skwarczyńska, Aspekt genologiczny "Fraszek” Jana Kochanowskiego, „Prace Polonistyczne” 1985, s. 54; J. Schulte, "Nie pieść się długo z mymi ksiq̨żeczkami”. „Fraszki” $i$ „Foricoenia” wobec epigramatu humanistycznego, w: tenże, Jan Kochanowski i renesans europejski. Osiem studiów, 


\section{Radosław Rusnak}

starożytności wzorcami gatunku, reprezentowanymi m.in. przez Gajusza Waleriusza Katullusa i Marka Waleriusza Marcjalisa ${ }^{5}$. Fraszki natomiast, pozbawione właściwie adekwatnych względem siebie rodzimych antecedencji ${ }^{6}$, miałyby być przedsięwzięciem wobec tamtej tradycji poniekąd osobnym, i to mimo licznych ich powinowactw $\mathrm{z}$ twórczością antyczną, nie wyłączając $\mathrm{z}$ tego także bezpośrednich trawestacji, przykładowo, utworów z Antologii greckiej.

Nie musi to być jednak cała prawda co do przyczyn zaobserwowanej tu rozbieżności. Wziąwszy pod uwagę, iż i jeden, i drugi z analizowanych tu neologizmów nosi w sobie określony znaczeniowy naddatek w stosunku do tradycyjnego rozumienia epigramu, a oba zbiory nie różnią się wcale aż tak znacznie, jeśli chodzi o formalno-tematyczny rozrzut pomieszczonych w nich wierszy, stwierdzić trzeba, że sedno problemu leżeć musi raczej w odmiennym zakorzenieniu obu rzeczowników w czytelniczej świadomości. Krótko mówiąc, rzecz nie tylko w tym, że Foricoenia opatruje się objaśniającym dopiskiem, zaś Fraszki nie, ponieważ te pierwsze odbierane są przez poetę w silniejszej zależności wobec klasyków, jako swoiste przedłużenie pozostawionej przez nich spuścizny, a te drugie jako nową, odseparowaną od nich jakość, ale i w tym, że łaciński tytuł takiej eksplikacji dla nieobytego z nim odbiorcy po prostu wymaga. „Fraszka” natomiast stanowi w owym 1584 roku leksem, przynajmniej w uzusie określonego środowiska, dostatecznie rozpoznany i zadomowiony.

By naświetlić bliżej podniesioną tu kwestię, nie wystarczy proste odwołanie się do czynnika czasu - oba zbiory ukazują się w tym samym roku, a trudno uznać, by zasób polskich fraszek zaczął się kształtować dużo wcześniej niż ten obejmujący ich łacińskie odpowiedniczki. Bardziej sensowna wydaje się nawet teza przeciwna, a to $\mathrm{z}$ racji dużo liczniejszych odniesień do okresu włoskich studiów poety w obcojęzycznej kolekcji. Poślednie znaczenie musi mieć tu też najpewniej rozbieżność pomiędzy językami pochodzenia obu neologizmów. Znów trudno założyć, by

przekł. K. Wierzbicka-Trwoga, red. K. Wierzbicka-Trwoga, M. Rowińska-Szczepaniak, Wydawnictwo Neriton, Warszawa 2012, s. 112.

5 Do Marcjalisa zresztą odwołuje sam urobiony przez Kochanowskiego neologizm. Jak przypomniał ostatnio w swej wyczerpującej analizie tej problematyki Wojciech Ryczek (tenże, „Domi et foris cenare...". O jednej z gier językowych Jana Kochanowskiego, w: Dobrym towarzyszom. Studia o "Foriceniach i „Fraszkach” Jana Kochanowskiego, red. R. Krzywy, R. Rusnak, Wydawnictwa Wydziału Polonistyki Uniwersytet Warszawski, Warszawa 2014, s. 25-49), forma „foricoenium" stanowi swoiste wypełnienie luki pozostawionej w języku łacińskim przez obecny w dorobku tego rzymskiego poety rzeczownik "domicoenium” (konkretnie w epigramatach V 78 i XII 77).

6 Odnośnie do owego pionierstwa Fraszek Krzywy pisze nawet: „Tak obszerna kolekcja epigramatów w języku wernakularnym, która realizuje postulaty estetyki renesansowej, kolekcja o przemyślanym, choć wciąż nie za bardzo dla nas jasnym, zamyśle artystycznym, to przedsięwzięcie unikatowe na skalę europejską" - tenże, Epigramatyczne księgi mistrza z Czarnolasu, w: Dobrym towarzyszom gwoli..., s. 19. 
poziom znajomości łaciny wśród pierwszych czytelników czarnoleskiego mistrza ustępował choć nieznacznie poziomowi obeznania z mową Dantego. Przyczyn wskazanego stanu rzeczy upatrywać należy jednak w czym innym. A mianowicie, w kluczowej w tym wypadku, różnicy pomiędzy twórczością pisaną po łacinie i tą w języku polskim. Ta ostatnia ma siłą rzeczy duże większe szanse, by przywoływany w niej po wielekroć - według wyliczeń Słownika polszczyzny Jana Kochanowskiego blisko $60 \mathrm{razy}^{7}$ - italianizm rozpowszechnić i w efekcie na trwałe wprowadzić do szerszego użytku.

Mówiąc o okresie sprzed pierwodruku Fraszek, mamy na myśli przede wszystkim ich niemożliwy dziś do pełnego przebadania obieg ustny, a że był on w przypadku wierszy tak silnie powiązanych z mnogimi aktorami ówczesnego życia publicznego z pewnością ożywiony, przekonują dobitnie odpowiednie świadectwa $\mathrm{z}$ epoki ${ }^{8}$. Dużo jednak rozleglejszy zakres potencjalnego oddziaływania, w porównaniu $\mathrm{z}$ jakimkolwiek tekstem przekazywanym $\mathrm{z}$ ust do ust, tudzież ręcznie transkrybowanym, przypisać należy jednak utworom drukowanym. A na tym polu edycję z 1584 r. wyprzedzają Treny (1580), w których interesujący nas rzeczownik pojawia się w aż trzech tekstach, w tym w słowach Brutusa z pamiętnego incipitu Trenu XI, ale przede wszystkim wcześniejszy o lat dokładnie dwadzieścia Satyr (1564). Istotne dla nas słowa padają w ramach tyrady, z jaką nobliwy dzikus występuje przeciw zepsuciu rycerskich obyczajów:

Niechaj drudzy, jako chcą, prawo rozumieją,

Niechaj pisać i mówić roztropnie umieją:

Za fraszkę ten wasz rozum stanie na ulicy,

Jeśli nie będzie pewny żołnierz na granicy.

$$
\text { (w. } 133-136)^{9}
$$

7 Fraszka, w: Słownik polszczyzny Jana Kochanowskiego, red. M. Kucała, t. 1 (a-h), Instytut Języka Polskiego PAN, Kraków 1994, s. 497-498.

8 Wzmianki takie znajdujemy m.in. w Polonicae grammatices institutio Piotra Stojeńskiego-Statoriusa oraz Dworzaninie polskim Łukasza Górnickiego. Zob.: J. Pelc, Kochanowski: szczyt renesansu w literaturze polskiej, Wydawnictwo Naukowe PWN, Warszawa 2001, s. 347.

9 Cyt. za: J. Kochanowski, Dzieła polskie, t. 1, wstęp i przyp. J. Krzyżanowski, PIW, Warszawa 1953, s. 68.

Wymienić wypada przy tej okazji jeszcze jeden, poprzedzający „editio princeps” Fraszek, jako że datowany na 6 października 1571 r., tekst Kochanowskiego, w którym leksem „fraszka” pojawia się, choć z uwagi na jego prywatny, a przede wszystkim rękopiśmienny charakter, nie da się jego ewentualnego zakresu oddziaływania w żaden sposób porównać ani z Trenami, ani z Satyrem - mowa tu o, wysłanym z Czarnolasu, liście poety do Stanisława Fogelwedera („Wiem, że takich fraszek do W. M. uszu nikt nie przynosi” - cyt. za: tamże, t. 3, Warszawa 1955, s. 278). 


\section{Radosław Rusnak}

Czy to jednak oznacza, że odpowiedzialność za rozpropagowanie rodzimej „fraszki” spoczywa wyłącznie na Kochanowskim? Zdecydowanie nie. Słownik polszczyzny XVI wieku wymienia choćby grupę autorów z różnych okresów zajmującego nas tu przedziału czasowego, u których napotkamy w druku rzeczony leksem. I mimo iż, jak się okaże, nie uwzględnia on wszystkich tekstów z epoki, z pewnością ukazuje swoją sporą zdatność tak dla szacunkowych ujęć skali zjawiska, jak i dla solidnej jego egzemplifikacji.

I tak, od momentu ukazania się pierwodruku Fraszek aż do końca stulecia wyraz ten odnotowujemy, prócz wymienionego już Pudłowskiego, m.in. u Sebastiana Fabiana Klonowica w jego poświęconych czarnoleskiemu mistrzowi Żalach nagrobnych (1585), później także w Worku Judaszowym (1600), w anonimowej Wyprawie plebańskiej (1590), w Harfie duchownej (1592) Marcina Laterny, w Gęślach różnorymych (1593) Jana Rybińskiego, w Potrójnym z Plauta (1597) Piotra Cieklińskiego, u Adama Paxiliusa w Komedyi o Lizydzie (1597) czy polskiej przeróbce Szymonowicowego Czystego Józefa. Ta względnie duża frekwencja w ostatnim szesnastoleciu wieku szesnastego łatwo daje się tłumaczyć powodzeniem drukowanej wersji epigramatycznej kolekcji Kochanowskiego, co nie powinno dziwić, zwłaszcza w odniesieniu do takich admiratorów czarnoleskiej Muzy, jak Klonowic czy Rybiński. Zależność tę uzmysławia dodatkowo nieco skromniejsza reprezentacja $\mathrm{w}$ tym wykazie tekstów $\mathrm{z}$ poprzedzającego ów okres dwudziestolecia, to jest lat 1564-1584. Znajdują się wśród nich m.in. Dworzanin polski (1566) Łukasza Górnickiego, Rozmowy chrystyjańskie (1575) oraz Epistomium (1583) Marcina Czechowica, polski przekład De republica emendanda Cypriana Bazylika (1577), Synonima latina (1579) Andrzeja Calagiusa oraz traktacik Olbrychta Strumieńskiego O spra-wie, sypaniu, wymierzaniu i rybieniu stawów (1573) ${ }^{10}$.

Zwrócić wypada tu jednak baczniejszą uwagę na dwa szczególne przypadki, a mianowicie na opublikowanego w 1564 r." Proteusa abo Odmieńca oraz o cztery lata późniejszą Historyję w Landzie (1568). W obu tych tekstach bowiem "fraszka” znaczy tyle, co „drobny utwór wierszowany” (fragmenty te brzmią odpowiednio: „Póki im fraszki piszesz, / To radzi czytają. / Piszże co statecznego, / Srodze się gniewają”12 oraz „I fraszkić pod czas czytać nie wadzi mądremu, / Gdy ich nie było

10 T. Z[awiszyna], Fraszka, w: Słownik polszczyzny XVI wieku, red. M.R. Mayenowa, t. 7 (F-Gończy), Zakład Narodowy im. Ossolińskich, Wrocław 1973, s. 131-132.

11 Sformułowana w wierszu dedykacyjnym uwaga o ofiarowaniu Proteusa na kolędę (tj. dzień 1 stycznia) roku 1564 każe samo zredagowanie tekstu lokować jeszcze przed końcem roku 1563, co tym bardziej czasowo zbliża do siebie oba pierwsze szesnastowieczne poematy satyrowe. Zwraca na to uwagę m.in. J. Nowak-Dłużewski, Okolicznościowa poezja polityczna w Polsce: czasy Zygmuntowskie, Instytut Wydawniczy PAX, Warszawa 1966, s. 290.

12 Cyt. za: Proteus abo Odmieniec. Satyra z roku 1564, wyd. W. Wisłocki, Akademia Umiejętności, Kraków 1890, s. 4, w. 57-60. 
ciężko snadź pisać drugiemu”’13). Zauważmy, iż sam Kochanowski posługuje się w druku tym wtórnym sensem przyswojonego przez siebie leksemu, a i tak w sposób niekoniecznie odnoszący się do twórczości epigramatycznej, dopiero kilkanaście lat później w Trenie II („Takie fraszki mnie zbierać pożyteczniej było”14). Takie literackie użycie leksemu w sposób bezwzględny odwołuje do zupełnie konkretnej części czarnoleskiego dorobku, którego znajomość w przypadku autora Proteusa wydaje się niezaprzeczalna ${ }^{15}$, a i twórca Historyi, pisząc o wspomnianym „drugim”, ma raczej na myśli nikogo innego, tylko właśnie Kochanowskiego.

Okazuje się jednak, że tak jak autorowi Odprawy trudno przyznać palmę pierwszeństwa, jeśli chodzi o poświadczone publikacją użycie wyrazu „fraszka” w sensie literackim, tak samo jest i w wypadku pierwszego w ogóle użycia tego leksemu $\mathrm{w}$ druku. Satyra bowiem wyprzedzają w tym względzie - nieznacznie wprawdzie, ale jednak - co najmniej dwa inne teksty. Jeden z nich odnotowany został przez Słownik polszczyzny XVI wieku, a jest nim Rozmowa albo dyjalog około egezekucyjej Korony Polskiej (1563) Stanisława Orzechowskiego. Służący bieżącej publicystyce tekst, jak się przypuszcza, powstał jesienią 1562 roku, tuż przed rozpoczęciem obrad sejmu piotrkowskiego, który rozpatrywać miał poruszane w Rozmowie kwestie, to znaczy przed dniem 30 listopada tego roku' ${ }^{16}$. Swojego pierwodruku doczekał się on w 1563 r., a już rok później wznowienia z nieco zmodyfikowanym tytułem: Dyjalog albo rozmowa około egzekucyjej... Dodajmy, że w obu wersjach utworu interesujący nas, a zaczerpnięty z jednej z wypowiedzi Ewangelika, fragment brzmi identycznie, mianowicie:

Ewangelik: Terazci dopiero wiem, co ksiądz u nas w Polszce jest; zaprawdę miałem go przedtem za fr a szkę, ale widzę, że zdrowie i żywot korony polskiej ksiądz jest; jakożby go tedy król upadłego dźwignąć przez tę exekucyją miał, powiedz nam" ${ }^{17}$. [podkr. - R.R.]

Drugi, nieuwzględniony jednak przez Słownik, casus to Historyja barzo ucieszna... o zburzeniu a zniszczeniu onego sławnego a znamienitego miasta i państwa trojań-

13 Cyt. za: Historya prawdziwa, która się stała w Landzie, mieście niemieckim, wyd. Z. Celichowski, Akademia Umiejętności, Kraków 1891, s. 43, w. 1399.

14 Cyt. za: J. Kochanowski, Treny, oprac. J. Pelc, Zakład Narodowy im. Ossolińskich, Wrocław 1972, BN I 1, s. 8, w. 7.

15 Zob. chociażby: J. Pelc, Jan Kochanowski w tradycjach literatury polskiej lod XVI do połowy XVIII w.), PIW, Warszawa 1965, s. 259-260.

16 J. Starnawski, Wstęp, w: S. Orzechowski, Wybór pism, oprac. J. Starnawski, Zakład Narodowy im. Ossolińskich, Wrocław 1972, BN I 210, s. XLXVIII-XLIX.

17 Cyt. za: Stanisława Orzechowskiego polskie dialogi polityczne („Rozmowa około egzekucyjej” i "Quincunx”), 1563-1564, wyd. J. Łoś, z obj. historycznymi S. Kota, Akademia Umiejętności, Kraków 1919, s. 52. Por. S. Orzechowski, Wybór pism, s. 373. 
skiego, znana też po prostu jako Historyja trojańska (1563). W obrębie tego anonimowego romansu mitologicznego na interesujący nas wyraz natrafiamy dwukrotnie. Pierwszy z przykładów jego użycia pojawia się w narracji poprzedzającej sam początek wojny. Związany jest z okolicznościami przygotowywania wyprawy pod zwierzchnictwem samego Parysa-Aleksandra, mającej wymóc na władcy Salaminy, Telamonie, zwrot pojmanej przez niego wcześniej siostry Pryjamusa, Hessyjony. Udział nieroztropnego Aleksandra w tej eskapadzie budzi poważne zastrzeżenia obdarzonego wieszczymi mocami Helenusa:

Ale Helienus z niejakiej wróżki a praktyki jął odradzać i napominać Priamusa, aby Parysa do Grecyjej nie słał, abowiem gdyby tam jechał a stamtąd do Trojej żonę sobie przyniósł, tedyby ostatnia była klęska państwu trojańskiemu, żeby i Troją zburzono, wywrócono, Priamusa by zabito, Hekubę i insze dzieci zabrano. Troilus zasię, młodszy brat, ganił Helienusowę radę, zowąc praktykę f r a s z k a mi a nikczemnymi rzeczami, iż był sam serca czystego, rycerskiego, równie takiego przyrodzenia jako Hektor, radził, aby bitwą a walką Hessiony Priamus dostawał a z wróżki się Helienusowej nie strachował ${ }^{18}$. [podkr. - R.R.]

Drugi z przykładów, co ciekawe, także dotyczy kwestii rysującej się w ciemnych barwach przyszłości oraz nadnaturalnych sposobów, dzięki którym objawia się ona przed żyjącymi. Oto Andromachę, pełną złych przeczuć co do losu męża, prześladuje sen, z którego wynika, „iż niedobrze było Hektorowi ku bitwie wychodzić dnia tego"'19. W nadziei zatem na zapobieżenie nadciągającemu nieszczęściu udaje się do samego Pryjamusa, by za jego pośrednictwem powstrzymać rzutkiego wojownika przed wyruszeniem tego akurat dnia do walki. Jak należy się spodziewać, reakcji Hektora na tę osobliwą interwencję daleko było do entuzjazmu. Czytamy, że „gdy się o tej rzeczy dowiedział, gniewał się barzo”20, a ponadto: „za f r a szk i to sobie ważył, co żona jego powiedała, co we śnie widziała, i uprzejmie kazał sobie zbroję przynieść i broń"21. [podkr. - R.R.]

Nietrudno spostrzec, że mimo zbieżności dat powstania obu utworów - choć przy uwzględnieniu, iż Rozmowa abo dyjalog pisana była raczej pod naciskiem chwili, Historyja natomiast na pewno nie mogła powstać w krótkim czasie, pierwszeństwo skłonni jesteśmy przyznać anonimowemu romansopisarzowi - wskazane tu użycia wiele jednak dzieli. O ile bowiem „fraszka” u Orzechowskiego przyna-

18 Cyt. za: Historya trojańska 1563, wyd. S. Adalberg, Akademia Umiejętności, Kraków 1896, s. 20-21.

19 Cyt. za: tamże, s. 69.

20 Cyt. za: tamże, s. 70.

21 Cyt. za: tamże. Dodać warto, iż w noszącym ślady wielu późniejszych interwencji drugim wydaniu Historyi (Wirzbięta, Kraków 1597) leksem ten pojawia się w pozycjach identycznych, co w pierwodruku. 
leży do tego semantycznego ciągu, którego punkt dojścia stanowią Fraszki w tytule epigramatycznej kolekcji (Ewangelik miał wcześniej swego rozmówcę za kogoś zdecydowanie pośledniego, a zatem za fraszkę), o tyle w Historyi trojańskiej daje o sobie znać poboczne, ale również znajdujące swoje potwierdzenie w piśmiennictwie wieku szesnastego, znaczenie tego wyrazu jako „wymysły, plotki, bajki”. Do tego typu bowiem postponujących kwalifikacji sprowadza się ocena wizji proroczej Helenusa z jednej, oraz sennej mary Andromachy z drugiej strony, jaką kwitują je Troilus z Hektorem. Na gruncie twórczości Kochanowskiego sens ten zaświadcza chociażby fraszka II 35 Do doktora: „Mówiłem ci, nie noś mi tych fraszek, doktorze, / Które tam czasem słyszysz w biskupiej komorze" (ww. 1-2), ale pojawia się on także w tekście Modrzewskiego-Bazylika.

Tak czy owak tym, co dla nas istotne, jest fakt, iż w momencie publikacji Rozmowy oraz Historyi sam zaczerpnięty z włoskiego leksem był już na tyle ugruntowany, i to od razu w co najmniej dwóch nieco różniących się od siebie rozumieniach, że trafić mógł na karty tekstu drukowanego, i to - rzecz warta odnotowania - bez jakichkolwiek dodatkowych precyzujących eksplikacji. I w jednym, i w drugim utworze używa się go tak, jak gdyby chodziło o wyraz szeroko znany i w polszczyźnie zadomowiony, przynajmniej w kręgach, do których swoje teksty obaj autorzy kierują.

Warto przy tej okazji wspomnieć o jeszcze jednym sensie, jaki leksem „fraszka” przyjmuje pod piórem Kochanowskiego-epigramatyka. Sens ów - nazwijmy go "genitalnym” - owszem, wychwytuje Słownik polszczyzny Jana Kochanowskiego, ale dopatruje się go wyłącznie w sformułowaniu: „Mam je drugie [fraszki - dop. R.R.], co je rad na sztych puszczę z wami, / A moim być na wirzchu, to ujrzycie sami" (Do paniej, II 9, w. 3-4) 22. Tymczasem na ewidentnej, co powyższy przykład jeszcze uprawdopodabnia, balansującej w zasugerowaną tu stronę ambiwalencji opiera się naszym zdaniem również koncept dystychu Do gościa (I 36): „Nie pieść się długo z mymi książeczkami, / Gościu, boć rzeką: »Bawisz się fraszkami«”. Takie odczytanie uzasadnia ponadto potwierdzona w materiale literackim polisemia czasownika „pieścić się”, które w dawnej polszczyźnie, nieco podobnie jak dziś, znaczy m.in. tyle, co „zajmować się czymś, dbać o coś, poświęcać czemuś dużo

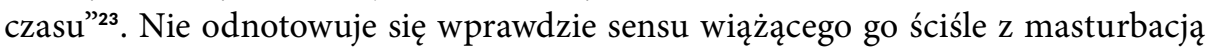
(choć pojawia się „pieścić się" jako odpowiednik łacińskiego „lascivire”, to jest „dogadzać sobie, sprawiać sobie przyjemność"), ale wobec adekwatnego sensu czasownika „pieścić”, jako „tulić, głaskać, dotykać z czułością"24, nie ma chyba przeciw-

22 Stownik polszczyzny Jana Kochanowskiego, s. 497.

23 E. S[abat], Pieścić się, w: Słownik polszczyzny XVI wieku, red. M.R. Mayenowa, t. 24 (Pi-Pniowy), Zakład Narodowy im. Ossolińskich, Warszawa 1996, s. 153.

24 Tenże, Pieścić, w: tamże, s. 152. 
skazań, by poszerzyć zakres semantyczny jego zwrotnego odpowiednika również o to znaczenie, które sugeruje tu najpewniej poeta.

Pomijając tu już wszelkie możliwe konsekwencje interpretacyjne swoistego utożsamienia w utworze Do gościa lektury epigramatów oraz onanizmu (porównywalna, zaznawana zasadniczo na osobności przyjemność?) zaznaczmy, iż tego typu rozszerzenie sensu pierwotnego: „drobiazg, błahostka” (motywowane nieznacznymi rozmiarami rzeczonych partii względem całego ciała, ale i ich „śmiesznością", przynależnością do groteskowej rzeczywistości karnawału, odsłanianych czy uwypuklanych dla wzbudzenia czystej wesołości), pozwala niejako zagarnąć w obręb przypisanych gatunkowi tematów również sferę doznań cielesnych, a o jej rozpowszechnieniu w zbiorze Kochanowskiego nikogo akurat nie trzeba chyba dodatkowo przekonywać.

Pozostaje pytanie, do jakich wniosków na temat kariery leksemu „fraszka” w piśmiennictwie drugiej połowy wieku XVI prowadzą zaprezentowane spostrzeżenia. Po pierwsze, Jan Kochanowski okazuje się nie być wcale pierwszym, który użył tego wyrazu w druku. Gdyby chcieć opatrzyć hasło „fraszka” w Słowniku jezyka polskiego adnotacją roczną, jak jest zwyczajem w różnych tego typu kompendiach zachodnioeuropejskich, zamiast 1564, czyli daty pierwszego wydania Satyra, widnieć w nim winien - przynajmniej w świetle naszej dotychczasowej wiedzy, rok 1563, czas publikacji zarówno Rozmowy albo dyjalogu, jak i Historyi trojańskiej. A gdyby pokusić się o daty roczne rzeczywistego zredagowania obu tekstów, to w przypadku Rozmowy byłby to rok 1562, w odniesieniu zaś do Historyi jakaś jeszcze odleglejsza, choć zupełnie już nieuchwytna, przeszłośćcs.

Po drugie, być może to nie czarnoleskiemu poecie powinniśmy przypisywać zaadaptowanie rzeczonego italianizmu, lecz właśnie Orzechowskiemu tudzież anonimowemu autorowi Historyi. Unikając ferowania jakichś rewolucyjnych wyroków w tej mierze, stwierdzić wypada, iż trudno wykluczyć sytuację całkiem analogiczną do tej, z jaką mamy do czynienia w przypadku tzw. literackie-

25 Podobny problem postawić można i w odniesieniu do fraszek znanych nam z wydania z 1584 r., a odnotowujących użycie tego wyrazu,. Nie wydaje się jednak, by w świetle obecnej wiedzy którąkolwiek z nich dało się datować na okres wyraźnie wcześniejszy aniżeli wskazany tu 1563 rok. Utworami powstałymi w latach sześćdziesiątych XVI stulecia są, z dużym prawdopodobieństwem, fraszki I 73 (Do P<awła> Stępowskiego), II 22 (Do Doktora), II 99 (Do Mikołaja Mieleckiego) oraz - jeśli przyjąć, iż poeta zwraca się w niej faktycznie do Ludwika Decjusza - fraszka I 29 (Do Jósta). Na najdokładniejszą datację, a zarazem bliską czasowo interesującego nas okresu, pozwolić sobie możemy wszakże jedynie w stosunku do pierwszej z tu wymienionych, a jej terminus ad quem stanowi data wyjazdu Stępowskiego do Italii (rok 1565). Fraszka II 99 z kolei powstać mogła, owszem, już w 1557, bo to wówczas Mielecki („dobry Starosta”) obejmuje starostwo chmielnickie, ale równie dobrze czas jej powstania przesunąć dałoby się aż do r. 1567, gdy awansował on na urząd kasztelański. Zob. stosowne objaśnienia do: J. Kochanowski, Fraszki, passim. 
go sensu „fraszki”, to znaczy że Kochanowski faktycznie wprowadził do zasobu leksykalnego polszczyzny włoski wyraz ${ }^{26} \mathrm{w}$ jego znaczeniu przenośnym, ponadto upowszechnił go własną, powstającą już wówczas twórczością epigramatyczną, lecz w kwestii użycia go po raz pierwszy w druku uprzedzili go inni, tak jak miało to miejsce w odniesieniu do Proteusa oraz Historyi w Landzie. Takie wszakże ujęcie domagałoby się dowiedzenia sieci (pewnych przynajmniej) wzajemnych kontaktów pomiędzy ówcześnie ledwie debiutującym poetą a oboma interesującymi nas tu twórcami.

Sprawa $\mathrm{z}$ autorem Historyi trojańskiej wydaje się dosyć prosta. Już Krzyżanowski w przekonywający sposób sugerował daleko idące zależności tego anonimowego romansu oraz ukończonego $\mathrm{z}$ końcem lat siedemdziesiątych, lecz zapewne opracowywanego dużo wcześniej tekstu Odprawy posłów greckich ${ }^{27}$. Ale jako argument koronny przyjąć chyba tu można nade wszystko zredagowanie przez Kochanowskiego, jak się przypuszcza na okoliczność opublikowania tej mitologicznej narracji, utworu Na historyją trojańska (fraszka II 74).

Na problemy natykamy się, gdy dociekać usiłujemy jakichkolwiek relacji pomiędzy autorem Zuzanny a Orzechowskim. Obu dzieli przynależność pokoleniowa. Sam okres włoskiej ekskursji twórcy Rozmowy albo dyjalogu (lata 1531-1541) - dodajmy, dostateczny dowód jego dobrej znajomości włoskiego - poprzedza o lat równo dwadzieścia analogiczne wyprawy młodego Kochanowskiego ${ }^{28}$. Choć ani jeden, ani drugi nie zdradzają wzajemnych powiązań między sobą czy to bezpośrednimi deklaracjami, bądź to przykładowo cytatami, na pewno da się powiedzieć o pewnej zbieżności tematycznej, jaką demonstruje ich twórczość, by tak rzec, obywatelska. Obserwacja ta odnosi się w szczególności do Rozmowy i Saty$r a$, obu powstałych w podobnym czasie, w dobie najgorętszych sporów wokół tzw. ruchu egzekucyjnego, obu też aprobatywnie odnoszących się do jego postulatów. Inne trudne do zignorowania „iunctim” stanowi też rodzina Tarnowskich. Dużą zażyłość Kochanowskiego z Janem Krzysztofem Tarnowskim, towarzyszem

26 Przyjmowane jako jeszcze jeden aksjomat włoskie pochodzenie "fraszki" też pod pewnymi względami mogłoby się okazać naszym zdaniem dyskusyjne. Gdyby bowiem zastanowić się nad brzmieniowym kształtem, jaki przyjmuje ona na gruncie języka polskiego, a chodzi tu o zastąpienie pierwotnego "s" szczelinowym „s", mimo iż wyobrazić by sobie można bez trudu także formę "fraska” (tak jak przykładowo: „łaska”, „laska”, „kolaska”), niebezzasadna wydaje się hipoteza o jakimś dodatkowym elemencie mediacyjnym, w postaci na przykład języka czeskiego, w którym adekwatny do naszego leksemu odpowiednik brzmi właśnie „fraška; identycznie brzmiącą formę zna też, odleglejszy od nas geograficznie i od czeszczyzny, serbsko-chorwacki (zob. S. Graciotti, dz. cyt., s. 225).

27 J. Krzyżanowski, Romans polski wieku XVI, PIW, Warszawa 1962, s. 41-43.

$28 \mathrm{Na}$ temat pobytu Orzechowskiego w Italii zob. H. Barycz, Studia włoskie Stanisława Orzechowskiego, w: tenże, Spojrzenia w przeszłość polsko-włoska, Zakład Narodowy im. Ossolińskich, Wrocław 1965, s. 171-195. 
jednej ze swoich italskich podróży, potwierdza czarnoleska poezja na wiele możliwych sposobów. Z kolei ojca Jana Krzysztofa, Jana Amora Tarnowskiego, łączy z Orzechowskim zdecydowanie ten sam krąg polityczno-towarzyskich koneksji. Obaj autorzy też czczą odrębnymi utworami - Epicedium oraz Żywot i śmierć Jana Tarnowskiego - zgon tego zasłużonego dla ojczyzny dyplomaty i wojownika ${ }^{29}$.

Czy tych kilka punktów wspólnych wystarcza wszakże, by założyć istnienie na tyle silnych pomiędzy oboma więzi, które uzasadniałyby sięgnięcie przez starszego $\mathrm{z}$ nich po leksem mocno, jak się wydaje, kojarzony z młodszym, jeszcze nie tak wpływowym, jak pod koniec swego życia, autorem polskich fraszek? Poprzestańmy na zachowaniu pewnej rezerwy co do takiej ewentualności (zastanawiająca jest chociażby czasowa zbieżność pojawienia się pierwszych drukowanych użyć rozważanego wyrazu z ostatecznym powrotem Kochanowskiego z jego italskich ekskursji) i sugestii, iż gdyby rzeczywiście zależało nam na odebraniu autorowi $S a$ tyra pierwszeństwa w posługiwaniu się wyrazem „fraszka”, przyznać należałoby je chyba raczej obdarzonemu określonym autorytetem i statusem Orzechowskiemu aniżeli anonimowemu redaktorowi Historyi, i to niezależnie od tego, jak niewiele wiemy na jego temat.

\section{Bibliografia}

Barycz Henryk, Studia włoskie Stanisława Orzechowskiego, w: Henryk Barycz, Spojrzenia w przeszłość polsko-włoską, Zakład Narodowy im. Ossolińskich, Wrocław 1965, s. 171-195.

Bedyniak Jarosław, Semantyka nazwy „fraszka” a konteksty kulturowe, „Pamiętnik Literacki" 2018, z. 1, s. 5-25.

Graciotti Sante, Fraszki i ,fraszki”. Z Padwy do Polski, w: Sante Graciotti, Od renesansu do oświecenia, t. 1, PIW, Warszawa 1991, s. 218-229.

Historya prawdziwa, która się stała w Landzie, mieście niemieckim, wydał Z. Celichowski, Akademia Umiejętności, Kraków 1891.

Historyja trojańska 1563, wydał S. Adalberg, Akademia Umiejętności, Kraków 1896.

Kochanowski Jan, Dzieła polskie, t. 1, wstęp i przyp. J. Krzyżanowski, PIW, Warszawa 1953.

29 Z powstałych ostatnio publikacji dotyczących Orzechowskiego wymienić można: K. Koehler, Stanisław Orzechowski i dylematy humanizmu renesansowego, Wydawnictwo Arcana, Warszawa 2004; Stanisław Orzechowski, pisarz polityczny. Materiały z konferencji naukowej w pięćsetlecie urodzin renesansowego humanisty: Przemyśl-Żurawica 17-18 października 2013, red. J. Musiał, Księgarnia Akademicka, Przemyśl-Kraków 2014. 
Kochanowski Jan, Fraszki, oprac. J. Pelc, Zakład Narodowy im. Ossolińskich, Wroclaw 1998, BN I 163.

Kochanowski Jan, Treny, oprac. J. Pelc, Zakład Narodowy im. Ossolińskich, Wrocław 1972, BN I 1.

Koehler Krzysztof, Stanisław Orzechowski i dylematy humanizmu renesansowego, Wydawnictwo Arcana, Warszawa 2004.

Krzywy Roman, Epigramatyczne ksiegi mistrza $z$ Czarnolasu, w: Dobrym towarzyszom. Studia o „Foriceniach $i$ „Fraszkach” Jana Kochanowskiego, red. R. Krzywy, R. Rusnak, Wydawnictwa Wydziału Polonistyki Uniwersytet Warszawski, Warszawa 2014, s. 9-24.

Krzyżanowski Julian, Romans polski wieku XVI, PIW, Warszawa 1962.

Lenart Mirosław, Patavium, Pava, Padwa. Tło kulturowe pobytu Jana Kochanowskiego na terytorium Republiki Weneckiej, Wydawnictwo IBL PAN, Warszawa 2013, Studia Staropolskie, Series Nova, t. XXXIII.

Nowak-Dłużewski Julian, Okolicznościowa poezja polityczna w Polsce: czasy Zygmuntowskie, Instytut Wydawniczy PAX, Warszawa 1966.

Orzechowski Stanisław, Wybór pism, oprac. J. Starnawski, Zakład Narodowy im. Ossolińskich, Wrocław 1972, BN I 210.

Pelc Janusz, Jan Kochanowski $w$ tradycjach literatury polskiej (od XVI do połowy XVIII w.), PIW, Warszawa 1965.

Pelc Janusz, Kochanowski: szczyt renesansu w literaturze polskiej, Wydawnictwo Naukowe PWN, Warszawa 2001.

Proteus abo Odmieniec. Satyra z roku 1564, wyd. W. Wisłocki, Akademia Umiejętności, Kraków 1890.

Ryczek Wojciech, „Domi et foris cenare...”. O jednej z gier językowych Jana Kochanowskiego, w: Dobrym towarzyszom. Studia o „Foriceniach i „Fraszkach” Jana Kochanowskiego, red. R. Krzywy, R. Rusnak, Wydawnictwa Wydziału Polonistyki Uniwersytet Warszawski, Warszawa 2014, s. 25-49.

Schulte Jörg, Jan Kochanowski i renesans europejski. Osiem studiów, przekł. K. Wierzbicka-Trwoga, red. K. Wierzbicka-Trwoga, M. Rowińska-Szczepaniak, Wydawnictwo Neriton, Warszawa 2012.

Skwarczyńska Stefania, Aspekt genologiczny „Fraszek” Jana Kochanowskiego, „Prace Polonistyczne" 1985, s. 53-86.

Stownik polszczyzny XVI wieku, red. M. R. Mayenowa, t. 24 (Pi-Pniowy), Zakład Narodowy im. Ossolińskich, Warszawa 1996.

Stownik polszczyzny Jana Kochanowskiego, red. M. Kucała, t. 1 (a-h), Instytut Języka Polskiego PAN, Kraków 1994.

Stanisław Orzechowski, pisarz polityczny. Materiały z konferencji naukowej w pięćsetlecie urodzin renesansowego humanisty: Przemyśl-Żurawica 17-18 października 2013, red. J. Musiał, Księgarnia Akademicka, Przemyśl-Kraków 2014. 
Stanisława Orzechowskiego polskie dialogi polityczne („Rozmowa około egzekucyjej” i „Quincunx”), 1563-1564, wyd. J. Łoś, z obj. historycznymi S. Kota, Akademia Umiejętności, Kraków 1919.

Starnawski Jerzy, Wstęp, w: S. Orzechowski, Wybór pism, oprac. J. Starnawski, Zakład Narodowy im. Ossolińskich, Wrocław 1972, BN I 210.

Radosław Rusnak

\title{
Jeszcze w sprawie genezy terminu „fraszka”
}

\author{
Streszczenie
}

Autor, rozważając sposoby rozumienia leksemu „fraszka” przez Jana Kochanowskiego, poddaje w wątpliwość tezę Sante Graciottiego, jakoby nie pojawił się ani razu w twórczości pisarza genologiczny sens tego leksemu. Za dostateczny dowód, iż jest inaczej, uznaje on opatrzenie przez czarnoleskiego poetę takim a nie innym tytułem swej obszernej epigramatycznej antologii w momencie porządkowania dorobku całego życia, a potwierdzenie, iż sens ten doczekał się rychłego zadomowienia, przynosi wydany krótko potem zbiór Melchiora Pudłowskiego Fraszek księga pierwsza (1586). W drugiej części artykułu próbuje się ustalić, komu należy przypisać pierwszeństwo, jeśli chodzi o użycie wyrazu „fraszka” w druku. Jak się okazuje, u samego Kochanowskiego leksem ten po raz pierwszy pojawia się w Satyrze (1564), wyprzedzają go natomiast nieznacznie zarówno Rozmowa albo dyjalog około egzekucyjej (1563) Stanisława Orzechowskiego, jak i anonimowa Historyja trojańska (1563).

Słowa kluczowe: fraszka; epigramat; Fraszki; Satyr; Jan Kochanowski; Stanisław Orzechowski; Historyja trojańska

\section{A few more words on the notion of "fraszka"}

Summary

Author, pondering over various meanings of "fraszka" in the work of Jan Kochanowski, expresses his doubts in regards of Sante Graciotti's thesis, claiming there is no one single case of its genological use in it. Sufficient enough to prove it wrong is the fact of him naming his epigrammatic collection - simultaneously to the 
process of putting in proper order his output - with the use of nothing other but this exact notion. The impending appropriation of such a use in Polish language has been shortly after confirmed by Melchior Pudłowski's Fraszek księga pierwsza (1586). In further part of the article author tries to establish the precise moment of the first ever use of the word "fraszka" in print. As it turns out, although Kochanowski makes a use of it for the first time in his Satyr (1564), he was slightly preceded by both Stanisław Orzechowski's Rozmowa albo dyjalog około egzekucyjej (1563) and anonymous Historyja trojańska (1563).

Keywords: fraszka; epigram; Fraszki; Satyr; Jan Kochanowski; Stanisław Orzechowski; Historyja trojańska

Dr Radosław Rusnak - (ur. 1978 r.), absolwent Wydziału Filologicznego Uniwersytetu Wrocławskiego, historyk literatury polskiego renesansu i baroku, edytor, tłumacz, autor książek Seneca noster, cz. I: Studium o dawnych przekładach tragedii Seneki Młodszego oraz „Elegii ksiag czworo” Jana Kochanowskiego - w poszukiwaniu formuly zbioru. 